\title{
Studies of genetic variability, heritability and genetic advance in balsam (Impatiens balsamina L.)
}

\section{Sumit Pal*}

Department of Horticulture, Institute of Agricultural Sciences, Banaras Hindu University, Varanasi-221 005 (U.P.), India

Anil K. Singh

Department of Horticulture, Institute of Agricultural Sciences, Banaras Hindu University, Varanasi-221 005 (U.P.), India

\section{A. K. Pal}

Department of Horticulture, Institute of Agricultural Sciences, Banaras Hindu University, Varanasi-221 005 (U.P.), India

\section{Anjana Sisodia}

Department of Horticulture, Institute of Agricultural Sciences, Banaras Hindu University, Varanasi-221 005 (U.P.), India

Anupam Tiwari

Department of Horticulture, Institute of Agricultural Sciences, Banaras Hindu University, Varanasi-221 005 (U.P.), India

*Corresponding author. E-mail: sumitpal4725@gmail.com

\begin{abstract}
A field experiment was carried out with 34 genotypes of Balsam (Impatiens balsamina L.) to assess the variability, heritability and genetic advance with an objective to identify superior genotypes for further crop improvement programme. The experiment was conducted during rainy season 2014 at the Horticulture Research Farm, Department of Horticulture, Institute of Agricultural Sciences, Banaras Hindu University, Varanasi. These genotypes show significant variation at $5 \%$ level of significance for different characters under study. Highest range of variation was reported with the number of flowers/plant (109-221). The phenotypic coefficient of variation (PCV) and genotypic coefficient of variation (GCV) was maximum for seed yield/plant, i.e. 29.02 and 26.34 while, minimum in case of length of leaf, i.e. 8.35 and 6.48 , respectively. High heritability was observed for all the characters except plant height, width of leaves and duration of flowering. Maximum heritability was recorded for duration of flowering $(90.68 \%)$ and minimum was observed in width of leaf $(30.04)$. High heritability $\left(h^{2}=90.64\right)$ with high genetic advance $(\mathrm{GA}=71.36)$ as percentage of mean was observed for number of flowers/plant, which indicated that additive gene effects were more important for that trait. High genetic advance as per cent of mean was observed for number of flowers/plant (71.36) however, lowest for floral bud diameter $(0.11)$ which indicates the preponderance of additive genes and selection will be effective for improvement of these traits.
\end{abstract}

Keywords: Balsam, Genetic advance, Heritability, PCV and GCV

\section{INTRODUCTION}

Balsam (Impatiens balsamina L.) is a widely grown flowering plant and it belongs to the family Balsaminaceae and native to India. Balsam is commonly known as garden balsam, rose balsam and Gulmehdi in Hindi (Singh, 2014). It is qualitative short day, free flowering, semi hardy and compact plant. It can withstand heavy rains and high humidity in atmosphere than any other annuals, balsamina is one of the popular species of north India (Lim, 2014). The flowers are used to prepare a red dye (Pal et al., 2018) and used for finger and toe nails and cosmeticsas a substitute for Henna (Lawsonia inermis). The seed oil can

\section{Article Info}

DOI: 10.31018/jans.v10i2.1702

Received: March 8, 2018

Revised: May 5, 2018

Accepted: May 22, 2018

\section{How to Cite}

Pal, S. et al. (2018). Studies of genetic variability, heritability and genetic advance in balsam (Impatiens balsamina L.). Journal of Applied and Natural Science, 10(2): $810-812$
- be used for burning lamps and in the surfacecoating industry. Seeds of balsam are in great demand in India and abroad. Therefore, for obtaining good growth and quality flowers, it is necessary to standardize the genotypes for producing good quality flowers. In order to make this flower popular among the growers and traders it is of utmost importance that some outstanding varieties must be available to the growers. Although several works have been accomplished for realizing this goal of developing superior varieties but the actual progress needed has not been achieved till now. In order to develop a genetically superior variety through selection in available genotypes a sound 
Pal S. et al. / J. Appl. \& Nat. Sci. 10 (2): 810 - 812 (2018)

knowledge of the extent of genetic variation, heritability of various traits related to growth, flowering and seed yield and the estimation of expected genetic gain from selection for these traits could become the foundational step in the improvement ornamental crops like balsam.

\section{MATERIALS AND METHODS}

The present investigation was conducted at Horticulture Research Farm, Department of Horticulture, Institute of Agricultural Sciences, Banaras Hindu University, Varanasi, U.P. during rainy season i.e. from August 2014 to November, 2014. The experiment consisted of 34 balsam genotypes in the form of seeds. All the genotypes were sown during July 2014 in nursery beds. Raised nursery beds were prepared of $3 \mathrm{~m} \times 1 \mathrm{~m} \times 0.15$ $\mathrm{m}$ size. Well rotten farm yard manure was incorporated at $5 \mathrm{~kg} / \mathrm{m}^{2}$. Seeds of each germplasm were sown evenly in a well managed nursery for raising seedlings. The seed bed was finally covered with paddy straw and sprinkled with water. Paddy straw was removed as soon as seed germination started. The experiment was laid out in a Randomized Block Design (RBD) with three replications. Seedlings having uniform growth and vigour were transplanted at a spacing of $60 \times 60$ $\mathrm{cm}$. The observations were recorded on randomly selected five plants from each genotypes for the characters viz, number of primary branches/plant, number of secondary branches/plant, plant height, plant spread, days taken to flowering, duration of flowering, flower longevity, number of flowers/ plant, 1000 seed weight and seed yield/plant. Variability parameters were worked out as per method given by Burton and Devane (1953) and heritability in broad sense was calculated as per the formula given by Hanson et al., 1956. Genetic advance as percent of mean was calculated according to the formula given by Lush (1940) and Johnson et al. (1995).

\section{RESULTS AND DISCUSSION}

The mean, range, genotypic and phenotypic coefficient of variation (GCV and PCV), heritability and genetic advance as percent of mean for all the traits are presented in table-1. Analysis of variance revealed that mean square due to genotypes were significant for various important parameters under study viz., plant height, plant spread, stem diameter, number of primary branches/plant, leaf length, leaf width, days taken to flowering, flower longevity, flower diameter, number of flowers/ plant, 1000 seed weight and seed yield/plant. This concluded the existence of wide range of variability for different traits which revealed that considerable improvement can be made in Impatiens balsamina. Mean performance revealed that a single genotype was not superior for all traits.

The genotypic coefficients of variation (GCV) estimates were less than phenotypic coefficient of variation $(\mathrm{PCV})$ with respect to all the quantitative traits probably due to presence of little amount of environmental effects. Narrow differences observed between genotypic and phenotypic coefficient of variation showing that variability existing among different genotypes of balsam was mainly due to genetic causes and there is less environmental influence on the expression of these traits hence, the selection may be misleading. Similar result was also advocated by Patnaik and Mohanty (2002), Namita et al. (2008) and Singh and Singh (2010) in marigold. Among all the genotypes of Impatiens balsamina, phenotypic and genotypic coefficient of variation were higher for seed yield/plant (29.02 and 26.34), number of primary branches/plant (23.85 and 22.23$)$ respectively, duration of flowering and number of flowers/ plant which indicated that these traits were relatively more variable among the genotypes studied as compared to other traits. Phenotypic and genotypic coefficient were less for length of leaves, width of leaf, days to bud initiation, flower diameter, bud diameter, duration of flowering and days taken to flowering. Observation of Singh and Sen (2000) was in close conformity with the present

Table 1.Estimation of variance and other genetic parameters in Impatiens balsamina.

\begin{tabular}{llllllll}
\hline Traits & Range & $\begin{array}{c}\text { General } \\
\text { Mean } \pm \text { SE }\end{array}$ & $\begin{array}{l}\text { Phenotypic } \\
\text { variance }\end{array}$ & $\begin{array}{l}\text { Genotypic } \\
\text { variance }\end{array}$ & PCV & $\begin{array}{l}\text { GCV } \\
\text { Heritability } \\
\left.\mathbf{h}^{2} \%\right)\end{array}$ & $\begin{array}{l}\text { Genetic } \\
\text { advance }\end{array}$ \\
\hline Plant height (cm) & $52.66-84.00$ & $75.02 \pm 4.43$ & 121.37 & 62.32 & 14.68 & 10.52 & 51.34 \\
Plant spread (cm) & $26.33-61.16$ & $42.61 \pm 2.60$ & 123.98 & 103.58 & 26.12 & 23.88 & 83.55 \\
No of primary branches & $3.83-8.00$ & $6.43 \pm 0.44$ & 1.81 & 1.22 & 20.91 & 17.19 & 67.60 \\
No. of secondary branches & $6.46-16.01$ & $11.91 \pm 0.59$ & 8.07 & 7.02 & 23.85 & 22.23 & 86.89 \\
Length of leaves (cm) & $9.66-12.36$ & $11.00 \pm 0.33$ & 0.84 & 0.50 & 8.35 & 6.48 & 60.01 \\
Width of leaves (cm) & $1.83-2.68$ & $2.23 \pm 0.14$ & 0.08 & 0.02 & 13.14 & 7.20 & 30.04 \\
Days to bud initiation (days) & $21.83-31.16$ & $26.37 \pm 0.87$ & 10.68 & 8.38 & 12.39 & 10.97 & 78.40 \\
Days taken to flowering & $25.00-37.00$ & $32.14 \pm 1.19$ & 16.31 & 12.02 & 12.56 & 10.78 & 73.66 \\
Duration of flowering (days) & $40.00-61.00$ & $51.02 \pm 1.11$ & 39.97 & 36.24 & 12.39 & 11.80 & 90.68 \\
Flower longevity (days) & $4.00-6.86$ & $5.57 \pm 0.39$ & 1.27 & 0.81 & 20.26 & 16.23 & 64.16 \\
Bud diameter (cm) & $0.59-0.89$ & $0.74 \pm 0.02$ & 0.0073 & 0.0048 & 11.52 & 9.30 & 65.21 \\
Diameter of flower (cm) & $3.06-4.12$ & $3.57 \pm 0.13$ & 0.09 & 0.04 & 8.69 & 5.60 & 41.47 \\
No. of flowers/plant & $109.00-221.00$ & $163.04 \pm 6.75$ & 1460.95 & 1324.14 & 23.44 & 22.31 & 90.64 \\
1000 seed weight (g) & $7.16-10.60$ & $9.02 \pm 0.25$ & 1.33 & 1.13 & 12.78 & 11.78 & 85.00 \\
Seed yield/plant (g) & $9.13-23.43$ & $16.98 \pm 1.19$ & 24.31 & 20.02 & 29.02 & 26.34 & 82.00 \\
\hline
\end{tabular}

${ }^{*} \mathrm{PCV}=$ Phenotypic coefficient of variance, ${ }^{* *} \mathrm{GCV}=$ Genotypic coefficient of variance 
findings.

Highest GCV was found for seed yield/plant (26.34), followed by plant spread (22.88) likewise highest phenotypic coefficient of variation (PCV) was recorded for seed yield/plant (29.02) followed by plant spread (26.12) followed by number of secondary branches (23.85) and number of flowers per plant (23.44), whereas lowest PCV was observed in length of leaves (8.35). Similarly Mishra et al. (2003) and Kumar and Patil (2003) observed similar findings for days to flowering in dahlia and China aster, respectively.

The magnitude of heritability is an important aspect of studying the nature of variation which is one of the basic criteria for determining the effectiveness of selection of variety/genotype (Panse and Sukhatme, 1967). The heritability estimates were higher for all characters studied except width of leaves, length of leaf, flower diameter, plant height flower longevity and bud diameter. Maximum heritability observed for duration of flowering (90.68) followed by number of flowers/plant (90.64), number of secondary branches/plant (86.89), 1000 seed weight (85.00), plant spread (83.55) and seed yield per plant (82.00) suggests that the variation exhibited by these traits were having more genetic basic rather than the environmental effects. The high estimation of heritability for these characters suggested that selection based on phenotypic performance would be more effective. Traits like number of flowers/plant and plant height exhibited high estimates of heritability coupled with high genetic advance. This suggests that the selection for these traits will highly fruitful for these traits are supposed to have higher magnitude of additive genetic variance which responds to selection.

The genetic advance as percent of mean ranged from $0.11 \%$ for bud diameter to $71.36 \%$ for number of flowers per plant. Highest values of genetic advance as percent of mean was recorded for number of flower per plant $(71.36 \%)$ followed by plant spread (19.16\%) and plant height (11.65\%), whereas lowest value was observed for bud diameter $(0.11 \%)$. Highest heritability with high genetic advance was observed for number of flowers/ plant, which is an indicative of the presence of additive gene and selection will be more rewarding for improving these traits, similar findings were also reported by Singh and Singh (2007) in balsam. High heritability accompanied with high genetic advance indicated that most likely the heritability was due to additive gene effects and selection may be effective for the number of flowers/plant.

\section{Conclusion}

Plant spread followed by number of flowers per plant had high enough GCV (23.88 and 22.31) and PCV (26.12 and 23.44), respectively. Number of flowers per plant had highest heritability with high genetic advance 90.64 and 71.36 , respectively. High estimates of GCV and heritability could be good predictors for improving the number of flowers/plant. Furthermore, moderate to high amount of heritability, GCV and GA\% in a mean could be explained by additive gene action and their improvement could be achieved through mass selection.

\section{REFERENCES}

Burton, G.W. and Devane, E.W. (1953). Estimating heritability in tall fescue (Jestuea arundinacea) from replicated clonal material. Agronomy Journal.45: 475-481.

Hanson, C.H., Robinson, H.F. and Comstock, R.E. (1956). Biometrical studies of yield in segregating populations of Korean lespedeza. Agronomy Journal.48: 268-72.

Johnson, H.W., Robinson, H.F. and Comstock, R.L. (1995). Estimates of genetic and environmental variability in soybean. Agronomy Journal.47: 314-28.

Kumar, H.R. and Patil, V.S. (2003). Genetic variability and character associations studies in China aster (Callistephus chenensis) genotypes. Journal of Ornamental Horticulture.6(3): 222-228.

Lim, T.K.(2014). Impatiens balsamina. In: Edible Medicinal and Non-Medicinal Plants. Springer, Dordrecht. pp 537-547.

Lush, J.L. (1940). Intra-sive correlation and regression of offspring on dams as a method of estimating heritability of characters. Proce: American Society of Animal Production.33: 295-302.

Mishra, M., Mohanty, C.R. and Mahapatra, K.C. (2001). Genetic variability with respect to floral traits in dahlia. Journal of Ornamental Horticulture.4(2): 79-82.

Namita, Singh, K.P, Raju, D.V.S., Prasad, K.V. and Bharadwaj, C. (2008). Studies on genetic variability, heritability and genetic advance in French marigold (Tagetus patula L.) genotypes. Journal of Ornamental Horticulture.12(1): 30-34.

Panse, V.G. and Sukhatame, P.V. (1967). Statistical Methods of Agriculture Workers, Indian Council of Agricultural Research, New Delhi.pp 58-67.

Pal, S., Singh, A.K., Sisodia, A., Pal, A.K. and Tiwari, A. 2018. Evaluation of double whorled balsam (Impatiens balsamina L.) genotypes for growth, flowering and seed attributes. Journal of Pharmacognosy and Phytochemistry. 7(2): 2901-2904.

Patnaik, N. and Mohanty, C.R. (2002). Genetic variability, heritability and genetic advance in African marigold (Tagetes erecta L.).Orissa Journal of Horticulture.30(2): 90-94.

Singh, A.K. and Singh, D. (2010). Genetic variability, heritability and genetic advance in marigold. Indian Journal of Horticulture.67: 132-6.

Singh, A.K. (2014). Breeding and Biotechnology of Flowers: Vol. 2 Garden flowers. New India Publishing Agency, New Delhi. p.698.

Singh, A.K. and Singh, N. (2007). Studies on genetic variability and heritability in balsam (Impatiens balsamina). Journal of Ornamental Horticulture.10(2): 128-130.

Singh, D. and Sen, N.(2000). Genetic variability, heritability and genetic advance in marigold. Journal of Ornamental Horticulture.3(2): 75-78. 